\title{
Entrepreneurial team and strategic agility: a conceptual framework and research agenda
}

Article

Accepted Version

Creative Commons: Attribution-Noncommercial-No Derivative Works 4.0

Xing, Y., Liu, Y., Boojihawon (Roshan), D. K. and Tarba, S. (2020) Entrepreneurial team and strategic agility: a conceptual framework and research agenda. Human Resource Management Review, 30 (1). 100696. ISSN 1053-4822 doi: https://doi.org/10.1016/j.hrmr.2019.100696 Available at https://centaur.reading.ac.uk/84474/

It is advisable to refer to the publisher's version if you intend to cite from the work. See Guidance on citing.

To link to this article DOI: http://dx.doi.org/10.1016/j.hrmr.2019.100696

Publisher: Elsevier

All outputs in CentAUR are protected by Intellectual Property Rights law, including copyright law. Copyright and IPR is retained by the creators or other copyright holders. Terms and conditions for use of this material are defined in the End User Agreement.

www.reading.ac.uk/centaur 
Central Archive at the University of Reading

Reading's research outputs online 


\title{
Entrepreneurial team and strategic agility:
}

\section{A conceptual framework and research agenda}

\begin{abstract}
To be agile, responsive and innovative seems to have become prerequisites for long-term growth and success for any organisations operating in an increasingly volatile, uncertain, complex and ambiguous (VUCA) world. This paper argues that such prerequisites, in turn, are dependent on the organization's abilities to harness team-level entrepreneurial behaviours, talents, quick and effective decision-making and related actions as drivers of continuous strategic agility and innovation through an effectively managed HRM process. It illustrates this argument by conducting a synthesized review of the literature streams of entrepreneurial team and strategic agility and developing a conceptual framework that links them together. Rooted in the micro-foundational perspective, this paper examines the relationship between key conceptual dimensions of entrepreneurial team and strategic agility; exploring the connections between these two literature streams. Our review postulates the potential value from a crossfertilization approach and points out the future research directions through which these literature streams might be advanced collectively. Our paper sheds light on the relationship between strategic agility and HRM through the lens of managing effective entrepreneurial teams in differing contexts.
\end{abstract}

Keywords: Entrepreneurial team, strategic agility, cognition, micro-foundation, HRM, context 


\section{Introduction}

The development of strong dynamic capabilities is necessary to foster the organizational agility that is crucial for tackling the ever-growing uncertainty generated by innovation and its associated dynamic competition (Teece, Peteraf, \& Leih, 2016). During times of rapid change and extreme threats, just 'steering the ship' may not be sufficient, and leaders must introduce approaches that tap their employees' and teams' energies throughout their organizations (Mohrman \& Worley, 2009). Thus, proposing a holistic framework by delineating team-level organizational practices and identifying HR mechanisms can facilitate organizations in achieving organizational agility in order to tackle uncertainty and change (Nijssen \& Paauwe, 2012), instigate the digital transformation in organizations (Bustinza, Gomes, VendrellHerrero, \& Tarba, 2018), or nurture much-needed leadership skills (Xing, 2016) in relation to strategic agility (Doz \& Kosonen, 2010).

Strategic agility has received vibrant and increasing attention from strategy and management academic community (Doz \& Kosonen, 2008; Weber \& Tarba, 2014). Essentially, the notion of strategic agility was coined in the theoretical domains of strategic change and renewal (Doz \& Kosonen, 2008). The prevailing understanding of strategic agility is how large and established incumbent organizations can shift, flex and renew themselves in order to respond to external uncertainty and turbulence while aiming to enact upon new opportunities (Weber \& Tarba, 2014). Being agile relates to an organization's innate capacity to be constantly adaptable to its changing environments, and such capacity rests at the individual and team level (Carmeli, Zivan, Gomes, \& Markman, 2017; Shafer, Dyer, Kilty, Amos, \& Ericksen, 2001). For instance, through their exploration of a tumultuous and largely unpredictable period in the industry, Shafer, et al (2001), highlighted the need to convert organizations from being basically stable and complacent to being agile, "nimble, and change-hardy", and emphasized the criticality of HRM strategies in the successful attainment of organizational agility. The 
importance of strategic agility — namely, the need for close alignment between business and HRM strategies - and the growing emergence of a strategic business partner role for HR professionals in the Indian context has been also reinforced (Ananthram \& Nankervis, 2013). Furthermore, drawing on theoretical insights in the areas of social exchange, microfoundations, positive work relationships, commitment, and dynamic capabilities, Carmeli, et al. (2017) suggested an HRM-based theoretical model that explains the three micro sociopsychological mechanisms by which buyers and suppliers can develop inter-organizational learning agility: respectful engagement, rich and ongoing communication, and advice seeking and giving.

Increasingly, developing capabilities of agility is therefore an ongoing concern of organizations of all types and sizes, but particularly those that see themselves as entrepreneurial as they strive to stay ahead, fresh, nimble, innovative and responsive to continuous change (Ganguly, Nilchiani, \& Farr, 2009). Extensive review of the agility literature shows that an agile organization can be successful in competitive environment through the abilities of responsiveness, competence, flexibility and speed to achieve a competitive advantage (Friedman, Carmeli, \& Tishler, 2016). Agility directly depends on the speed at which the company produces and distributes new products and achieves cost effectiveness. Reduction in production costs, increasing customer satisfaction, phasing out of activities not having valueadded and increasing competitiveness are salient benefits that can be attained through strategies and implementation of agility (Bottani, 2009).

However, most of the existing body of knowledge on strategic agility is derived from studies based on large and established organizations, such as multinational enterprises (MNEs). Studies on agility on small entrepreneurial firms and new ventures in differing contexts are yet few (e.g. Friedman et al. 2016). This paper argues that entrepreneurial ventures exhibit particular characteristics, different to those of the large, established incumbents, and which 
subsequently have important implications for how agility is depicted in such small, dynamic and turbulent contexts. Evidence suggests that small firms are not necessarily the most agile in rapidly changing and uncertain contexts if they do not possess the appropriate adaptive capacity. The challenges to stay agile for entrepreneurial ventures while different to their larger counterparts seem to be rooted in their inability to act or respond fast enough to seize the fleeting opportunities. Being quick to respond or adapt to changes or seize opportunities (i.e., Speed), therefore, is a complimentary trait of agility and is a matter of concern for all types and sizes of agile firms (Eisenhardt, 2013; Eisenhardt \& Bingham, 2017). Our focus therefore is not on agile firms per se, but on entrepreneurial teams' agility that characterize these firms, and the micro-level processes and dynamics that affects their ability to achieve and sustain agile irrespective of the size of the firms or industry contexts.

Entrepreneurial team agility is a team's ability to reach decisions quickly and respond to unpredictable changes in effective ways to take advantage of changing or emerging opportunities (Liu et al., 2015). Research has shown that the decision-making processes of effective agile teams differ considerably from those of less effective ones and that the process of making such decisions often entails strategic, operational, emotional and ethical implications that can 'critically affect (team and) organizational health and survival' (Eisenhardt \& Zbaracki, 1992). Although this issue has been largely studied by strategy and management scholars, the scholarly focus on the micro-processes that help transform team-level agile attributes into strategic action remains nascent (Hambrick, 1994, 2007) and scholars have encouraged to draw from Behavioural Theory to find explanations (Friedman et al., 2016; Kunc \& Morecroft, 2010). This theoretical lens can help identify how agile entrepreneurial team may utilize inherent behavioural factors to manage cognitive processes to effect quick actions and timely decisions (Cyert \& March, 1963). The Behavioural Theory of the Firm (Gavetti, Greve, Levinthal, \& Ocasio, 2012) argues that while small firms may operate under the guidance of 
the entrepreneur, larger firms include coalitions of individuals or teams that participate in setting goals and making decisions and their dynamics varies in respective industry contexts. Nevertheless, the issue of how agile entrepreneurial teams enact and facilitate strategic decision-making processes (Carmeli, Schaubroeck, \& Tishler, 2011), influence team processes and help to build adaptive capacity (Nadkarni \& Herrmann, 2010) remains elusive. Hambrick (1994) noted that a focus on top management team behavioural integration (BI), which refers to the extent to which an entrepreneurial team at the top is engaged in a mutual and collaborative or competitive interaction may elucidate the appropriate adaptive responses to changing environments (Snell, Snow, Davison, \& Hambrick, 1998), but this line of research still needs further conceptual development and empirical refinement, particularly in the context of agile entrepreneurial teams (Liu, Liu, Ding, \& Lin, 2015; Maloney, Bresman, Zellmer-Bruhn, \& Beaver, 2016).

Entrepreneurial teams constitute a core element of an entrepreneurial venture. The dynamism of an entrepreneurial venture relates to resources availability, team composition, and flexibility which hinges on the effective functioning of an entrepreneurial team at its core to determine the success or failure of such entrepreneurial new ventures (Klotz, Hmieleski, Bradley, \& Busenitz, 2014). Thus, entrepreneurial teams constitute an essential ingredient for entrepreneurial ventures' creation, growth and development (Eisenhardt, 2013; Wright \& Vanaelst, 2009). However, from an evolutionary perspective, team members can change over time situated along with the venture development and growth trajectory (Chandler, Honig, \& Wiklund, 2005). This evolutionary process may bring or lose firm-specific human capital resource (Ucbasaran, Westhead, \& Wright, 2008), that in turn can affect the quality of strategic decisions (Mathias \& Williams, 2014). Furthermore, we also argue that the unique characteristics of entrepreneurial ventures and SMEs at large, including resource constraints, dynamism, and organizational flexibility (Stokes et al., 2016), requires the HRM literature to 
be viewed as a promising and fruitful direction of how strategic agility within team structures can be enhanced in such contexts. For instance, a recent study investigating acquisitions found out that strategic agility can be better understood while being connected to HRM dimensions (Junni, Sarala, Tarba, \& Weber, 2015).

The notion of entrepreneurial team is therefore a multifaceted concept (Klotz et al., 2014; Mol, Khapova, \& Elfring, 2015). Research in management and organization studies also emphasized the important role of context in theorizing team research (Maloney et al., 2016). For instance, research in strategy and organization has shown that entrepreneurial teams (particularly at top level) — through their composition and their actions — can have a significant influence on the performance of entrepreneurial firms (Eisenhardt, 2013). In small firms, these teams often have greater agility to shape the course of their firms than executives of large, established firms (Jennings \& Beaver, 1997), although larger firms do attempt to be more agile in how they respond to entrepreneurial opportunities (Boojihawon, Dimitratos, \& Young, 2007). Nevertheless, attractive markets, favourable regulatory policies, and even luck, matter too. But, the core idea of this article is to highlight the important role of entrepreneurial teams - their composition, their experience, their decision-making capabilities, ability to learn, and organizational skills — in determining the performance of entrepreneurial firms.

By embracing some insights from a micro-foundational approach, we therefore argue that HRM concepts and theories may enhance the understanding of strategic agility and its boundary conditions in considering team-level entrepreneurship. Therefore, this paper aims to fill the gap of advancing strategic agility by examining entrepreneurial ventures with a focus on entrepreneurial team from a HRM perspective (Dufays \& Huybrechts, 2016; Hayton, 2005). Our purpose is to juxtapose entrepreneurial team and strategic agility, in order to identify the mechanisms and dimensions connecting these two research streams through the lens of HRM. 
We need micro-level analyses to improve our understanding of team-based capabilities and their ability to stay agile in different entrepreneurial contexts. As such, we ask: what are the HRM implications for how entrepreneurial teams are defined, constituted and developed in the pursuit of strategic agility and growth?

The remainder of this article is organized as follows. We first propose a conceptual framework linking entrepreneurial team and strategic agility. Then, we will review each of the dimensions and develop propositions, respectively. To conclude, we will discuss implications for theory development and practice, and suggest future research directions.

\section{Entrepreneurial team and strategic agility: A conceptual framework}

The ability of an entrepreneurial firm to demonstrate agility is very much dependent on how agile its teams are at the set up stage. For instance, in order to execute strategic choices as circumstances change, entrepreneurial teams must be defined, motivated and effectuated in the right composition and context, be well-equipped to capture new information, be agile and make quick decisions, corrections or adaptations, with an appropriate sense of timing because being too early or too late can be both costly (Glassman, Zell, \& Duron, 2014). For instance, in her examination of why some entrepreneurial ventures are more successful than others in 'highvelocity' settings (i.e., settings characterized by rapid, unpredictable, and frequent change around core features such as products, customers, demand, competition, and complementers). Eisenhardt (2013) illustrated how differences among top-level entrepreneurial teams often

shape the heterogeneous performance observed among entrepreneurial firms in similar environments. Indeed, the effectiveness of the entrepreneurial teams at the top has an enormous influence on the success of their entrepreneurial firms (Friedman et al., 2016). 
Furthermore, demonstrating agility and building up entrepreneurial teams is critical for growth. For instance, Jennings and Beaver (1997) assert that

“...competitive advantage in smaller firms often arises accidently as a result of the particular operating circumstances surrounding the enterprise, here, strategic management becomes primarily an adaptive process concerned with manipulating a limited amount of resources, usually, in order to gain the maximum immediate and short term advantage. In the small firm efforts are concentrated not on predicting and controlling the operating environment but on adapting as quickly as possible to the changing demands of the environment and devising suitable tactics for mitigating consequences of any threatening changes which occur" (p.64)

The speed and propensity for change is partly determined by the needs of the context in which the business operates, and is partly dependent upon the skills, personality and needs of the owner, manager or entrepreneur at the start. And as the firm grows, in size and complexity, the business demands a unique blending of team-level skills, experiences and talents to succeed thanks to exploiting existing competitive advantage to achieve superior performance. Naturally, inherent dynamism will also demand fluidity, flexibility and adaptability in order to lead to effective outcomes.

In any of these organizational contexts, research on strategy and organization suggests that strategy, as a linear, planned or top-down process, is a necessary but not a sufficient condition for successful implementation. The result is insights and emergent theory linking strategic decision making process to performance in entrepreneurial firms. This suggests that entrepreneurial teams and decision-makers can rarely identify all the contextual factors that will end up being of significance to their ventures, let alone predict how events will unfold. The practice of strategy therefore suggests that entrepreneurial teams have to accept, make and implement decisions often in a context of high uncertainty (Miller \& Ireland, 2005). And despite such uncertainty, how quickly an entrepreneurial team decides to respond to a particular change or opportunity has a direct influence on the success or failure. Therefore, speed tied up with effective decisions seems to be a key determinant for superior performance in fast 
changing and highly uncertain or VUCA environments. Entrepreneurial firms with embedded teams therefore need to possess and cultivate agility (Bingham \& Eisenhardt, 2011; Eisenhardt, 2013). This means developing capabilities identifying major changes in the external environment, quickly deploying resources to new courses of action in response to those changes, and recognise and act promptly when it is time to halt or reverse existing resource (including human resource) commitments (Khoshnood \& Nematizadeh, 2017). This strategic flexibility requires teams and decision-makers to find the right balance between committing the resources necessary to carry out a decision and avoiding investment into futile ventures.

\section{A conceptual framework on entrepreneurial team and strategic agility}

Insert Figure 1 about here

As noted by Gruber and MacMillan (2017), the existing research on entrepreneurial behaviours has been hindered by most studies having adopted a traditional perspective of the construct that is embedded in economic rationality and focussed primarily on for-profit ventures. Drawing on identity theory, the authors proposed a reconceptualization that stressed a broader "identity relevance" of entrepreneurial behaviours, referring to the different meanings that founders associate with entrepreneurship, such as establishing new ventures not strictly out of economic self-interest, but also out of concern for others-either in their communities or in society at large (Gruber \& MacMillan, 2017). This resonates with the notion of team identity and cognition in entrepreneurial contexts. Investigating the strategy formation process in general, and the fundamental tension between strategizing by "doing" versus "thinking" in particular is central to understanding why, in entrepreneurial settings, some firms create successful competitive advantages while others do not (Ott, Eisenhardt, \& Bingham, 2017). This aspect 
links to the availability, allocation, and orchestration of resources. Intriguingly, prior research sheds light on the texture of entrepreneurial cognition and on the little known relationship between cognition, action, amended cognitions, and redirected action. Specifically, it shows that, whereas entrepreneurial firms with headquarters in Singapore, the U.S., and Finland and with more successful foreign market entries decrease improvisation in opportunity selection but increase improvisation in opportunity execution, firms with less successful foreign market entries do the opposite (Bingham, 2009). Furthermore, in addressing the paradoxical tension between focus and flexibility that can define or break the entrepreneurial venture, another study explored when and where it is advisable to be focussed and disciplined, as opposed to being flexible and opportunistic (Bingham, Furr, \& Eisenhardt, 2014). Importantly, understanding how executives develop and implement successful strategies in high-velocity entrepreneurial settings is theoretically intriguing because it pushes beyond the boundary conditions of the traditional strategic logics of position and leverage to the less-understood opportunity logic, in which advantage is precarious and often short-lived (Eisenhardt \& Bingham, 2017). Examining successful firms such as Apple, Facebook, and Dropbox, Eisenhardt and Bingham's perspective combines two intertwined themes: first, taking a broader view of the strategic playing field, enabling a better visibility and comprehension of opportunities; and, second, putting in place the relevant structures organized at the "edge of chaos" that enable the flexible yet efficient seizing of opportunities. Collectively, these studies highlight the importance of attaining and sustaining agility for entrepreneurial ventures across diverse geographical, cultural, social, and institutional contexts.

As shown in Figure 1, we present a conceptual framework that connects entrepreneurial team and strategic agility through the notion of dynamics around opportunism and speed of decision making or responsiveness. The three dimensions of entrepreneurial team are interconnected with each other from the psychological micro-foundational perspective and will differ in 
contexts. For instance, team cognition can affect the process of team formation and composition, which, in turn, can influence team identity. When there are dynamic changes in team composition, team identity will be affected by collective cognition. In a similar vein, three dimensions of strategic agility are closely related with each other. Therefore, by taking a holistic approach, our conceptual framework offers high-level relationship between these two constructs, while the underlying mechanisms connect each dimension in individual construct can be identified. Because the interconnection and dynamics among each dimensions, the relationships can be complex and nuanced. As illustrated in the conceptual framework, the above causal relationships can be moderated by the dynamics of opportunities at play and the speed of decision making around them (Ucbasaran et al., 2008). To illustrate further depth, we develop some propositions that underpin these plausible relationships in the next sections.

\section{Entrepreneurial team from a micro-foundational and dynamic perspective}

In this section, we take a holistic view to synthesize the literature streams of entrepreneurial team along three dimensions of strategic agility, namely strategic sensitivity, resource fluidity, and leadership unity. In so doing, we aim to map out the underlying connections between entrepreneurial team and strategic agility, in order to elucidate how the juxtaposition of two literature streams may contribute to each other theoretically through a cross-fertilization approach.

\section{Entrepreneurial team cognition and strategic sensitivity}

Entrepreneurial cognition underpins the entrepreneurial behaviours. Previous research on cognition largely examines individual-level entrepreneurs and founders and how their cognition may affect entrepreneurial intention (Shepherd \& Krueger, 2002). A recent review suggests that cognition can also be played out at team-level, that may explain the variations of venture outcome and significantly influence new venture development (Mol et al., 2015). We 
endorse this approach in recognizing the importance of collective team cognition while aiming to articulate how entrepreneurial team cognition can affect strategic sensitivity (West, 2007).

Strategic sensitivity relates to degree of alertness around opportunity exploration and exploitation. It demands an agile mindset at individual and team levels characterised by willingness, even eagerness, to change (Shafer et al., 2001). Under this mindset, looking out for opportunities is everyone's business, and mobilising quick response demands the capacity to quickly and easily make decisions and translate these decisions into action. At times, simply adding new team members can bring fresh ideas and experience beyond the existing team, that in turn may trigger new opportunities recognition and realization (Ensley \& Pearce, 2001). Opportunities may or may not reside in the boundary of existing team, and can vary on the degree or extent of change required. Sometimes only small or little adjustments or modifications are needed to respond to evolving customers' needs or competitors' actions. At others, some major adjustments are necessary in product offerings, business processes in order to support an effective strategy.

From the strategic decision making perspective, scholars argue it is the collective cognition, of the entrepreneurial team, not individuals, that can help make quick and reliable decisions, albeit under transformational leadership (West, 2007). In so doing, ensuring comprehensiveness of such fast decisions is a paramount activity in order to enable an effective response to the various needs and expectations of stakeholders. From a collective memory perspective, to facilitate decision-making comprehensiveness, entrepreneurial founding teams may develop transactive autobiographical memory systems, so as to improve their venture's long-term capacity to adapt (Bryant, 2014). The collective team cognition may facilitate knowledge transfer and performance for science-based entrepreneurial firms (Knockaert, Ucbasaran, Wright, \& Clarysse, 2011). Integrating knowledge in groups through formal interventions may enable flexibility (Okhuysen \& Eisenhardt, 2002). Furthermore, rational heuristics, or the 'simple 
rules' that strategists learn from process experience may facilitate to identify external opportunities (Bingham \& Eisenhardt, 2011). There is the need to compensate the limitation of individual members while leveraging the potential of team as a whole.

In multinational settings, cultural influences on entrepreneurial behaviours affect the way entrepreneurs deal with uncertainty both an individual and team levels (Liu \& Almor, 2016). Also, corporate languages from a cross-cultural perspective can affect strategic agility development (Brannen \& Doz, 2012). A recent study also suggests that Eastern culture tends to embrace uncertainty and ambiguity as a source of intelligence in management practices (Xing \& Liu, 2015). The international cultural context may further complicate the entrepreneurial team cognition. One recent study based on returnee and domestic entrepreneurs in China found entrepreneur team's domain-specific expertise can influence their causation or effectuation logic (two distinctive logics of reasoning) in the pursuit of entrepreneurial opportunities (Liu \& Isaak, 2016). Hence, when entrepreneurial team contains members who are bi-culturalism, it may enhance the cognitive complexity on the team-level.

Hence, we posit the following:

Proposition 1: Entrepreneurial team cognition is positively correlated with the propensity of strategic sensitivity to enact upon opportunity.

\section{Entrepreneurial team composition and resource fluidity}

Entrepreneurial team composition is an important determinant for ventures' performance (Hmieleski \& Ensley, 2007). The board composition and top management team ownership structure, for example, can influence post-IPO performance in young entrepreneurial firms (Kroll, Walters, \& Le, 2007). One study based on 79 entrepreneurial teams found out team 
process variables positively influence team effectiveness (Chowdhury, 2005). This finding corroborates with the importance of team entrepreneurial formation process based on the case study of a research-based spin-off (Clarysse \& Moray, 2004). Factors associated with member entry and exit in entrepreneurial founder teams have been suggested, such as the size of the founding team was significantly negatively associated with subsequent team member entry, functional heterogeneity was positively associated with team member entry. Heterogeneity of prior entrepreneurial experience was positively associated with team member exit (Ucbasaran, Lockett, Wright, \& Westhead, 2003). Hence, this dynamic aspect relates to the HRM implications of entrepreneurial team composition. Resource-seeking and interpersonal attraction are identified as primary motivators for new member addition in the process of entrepreneurial team formation (Forbes, Borchert, Zellmer- Bruhn, \& Sapienza, 2006).

Resource fluidity refers to the ease and speed with which financial, physical, intangible, and human resources can be moved around from less to more promising opportunities. In effect, mobilizing rapid response relates to the capacity to quickly and easily make decisions and translate these decisions into action. In some cases, this involves little more than making a series of relatively small-scale accommodations to evolving customer needs or competitors' initiatives. In other words, it involves making major adjustments in product or service offerings or critical business processes. Both antecedents and consequences of team compositions bear significant implications for resource acquisition and fluidity when it comes to innovation (Packalen, 2007).

The work of Carnes and al. (2017), for instance, has shed light on how managers of firms in different life-cycle stages orchestrate resources differently to develop innovation quickly and effectively. They suggest that an understanding of the most influential resource orchestration actions in early and growth stages of development can be helpful to managers (including HR managers) responsible for planning, guiding, and fostering organic organizational growth, or 
enabling the transition from one stage to another. Specifically, managers need to be able to identify and acquire the most suitable resources and develop the most effective capabilities and compositions to produce the amount and type of innovation needed to achieve and maintain competitive advantages. Related prior research identified two types of resources that are closely linked to entrepreneurial team compositions, namely (1) financial resources and (2) human capital and social capital resources. The finance literature (Hsu, 2007; Zimmerman, 2008), has documented the relationship between entrepreneurial team and financial resources acquisition. For instance, top management team heterogeneity can affect the capital raised through an initial public offering (Zimmerman, 2008). Furthermore, prior founding experience (especially financially successful experience) increases the likelihood of Venture Capital (VC) funding and venture valuation (Hsu, 2007). A recent study based on carbon nanotechnology industry suggested that entrepreneurial team can secure VC investment when spanning 'science' and 'technology' categories through team hybridization (Wry, Lounsbury, \& Jennings, 2014). Hence, entrepreneurial team composition significantly influences financial resources attainment.

Another important resource relates to human capital and social capital (Gedajlovic, Honig, Moore, Payne, \& Wright, 2013; Mosey \& Wright, 2007; Wright, Hmieleski, Siegel, \& Ensley, 2007). A meta-analytical review reveals human capital largely determines entrepreneurial success (Unger, Rauch, Frese, \& Rosenbusch, 2011). Based on young high technology firms in Silicon Valley, one study found that prior human capital experience is consistently associated with positive firm outcomes (Beckman, Burton, \& O'Reilly, 2007). Entrepreneurial teams' social ties with external advice networks can influence their agile performance (Vissa \& Chacar, 2009). Entrepreneurial team members' ability to develop relational capital (trust, identification, and mutual obligation) can be developed through caring about one another's needs and making expectations explicit clearly and rapidly (Blatt, 2009). From a psychological 
micro-foundational perspective, the notion of human capital resources emerged linking a multilevel analysis (Ployhart \& Moliterno, 2011). Firm specific human capital is associated with the characteristics of firms (Coff \& Raffiee, 2015). Entrepreneurial firms can link with specific human capital as well. Furthermore, entrepreneur's specific human capital is conducive to capturing opportunities (Ucbasaran et al., 2008). A recent study assessed a resourced-based theorizing on firm growth and suggests a dynamic perspective can help to better articulate firm growth and performance (Nason \& Wiklund, 2015). Hence, we argue a nuanced understanding of entrepreneurial team composition can advance the theoretical articulation on resource mobilization and firm performance in seeking strategic agility. Hence, we posit the following:

Proposition 2. Entrepreneurial team composition is positively correlated with resource fluidity, whereas the more heterogeneous entrepreneurial team is, the more fluid is the resource orchestration.

\section{Entrepreneurial team identity and leadership unity}

Entrepreneurial identity can be viewed as a fluid and multifaceted construct that relates to entrepreneurs, entrepreneurial ventures, and its surrounding broader environment (Fauchart \& Gruber, 2011; Powell \& Baker, 2014). The recent scholarly advancement development on entrepreneurial identity suggests a dynamic process view on identity formation and identity work, rather than a static analysis approach focusing on identity itself (Leitch \& Harrison, 2016). Entrepreneurial identity can have important bearing on entrepreneurial behaviours and activities. For instance, entrepreneurial identity and legitimate distinctiveness can influence investor judgments of a new venture's plausibility (Navis \& Glynn, 2011). Related, the legitimate distinctiveness of new venture can be socially constructed through entrepreneurs' narratives and arguments with stakeholders (van Werven, Bouwmeester, \& Cornelissen, 2015). Furthermore, founder's identity can shape firm's varying strategic responses to resource- 
constrained adverse situation or given opportunities (Powell \& Baker, 2014). Such adversity requires entrepreneurs to realise a certain level of resilience and flexibility to cope with the demands and urgency of such situations in order for their ventures to thrive (Cooper, Liu, \& Tarba, 2014; Liu, 2018). Entrepreneurial identity can be conducive to the emergence of new market categories, as illustrated by the research on US satellite radio (Navis \& Glynn, 2010). However, the existing research on entrepreneurial identity paid less attention to the notion of entrepreneurial team identity, which is collective and dynamic in teams.

Based on the dynamic view, we will examine the research stream on Top Management Team (TMT), identity work, and organizational change to show linkages and elaborate on the relationship between entrepreneurial team identity and leadership unity. TMT and shared leadership vision can significantly influence agile performance (Ensley, Pearson, \& Pearce, 2003). The cohesion and potential conflicts among entrepreneurial teams are closely related to the team identity (Ensley, Pearson, \& Amason, 2002). In particular, the speed, fluidity and dynamic aspect of team identity is associated with the changes in entrepreneurial team compositions over time (Chandler et al., 2005). The interaction between TMT and boards represents the shared leadership identity in new ventures (Knockaert, Bjornali, \& Erikson, 2015). Furthermore, TMT behavioural integration in facilitating the pursuit of both an exploitative and exploratory orientation can enhance the performance of SMEs (Lubatkin, Simsek, Ling, \& Veiga, 2006). Another study found CEO-TMT communication richness and power decentralization facilitates organizational ambidexterity in high-tech SMEs (Cao, Simsek, \& Zhang, 2010). Hence, team identity and TMT are closely related to collective commitment on the team-level.

Entrepreneurs' identities can also influence how entrepreneurs pursue, select, and evaluate opportunities (Mathias \& Williams, 2014). Depending on the assumption of role identity, entrepreneurs attend to different opportunity features and make different decisions to consider 
and select opportunities. One recent study shows that social identity of an entrepreneur influences his or her entrepreneurial behaviour, either causation or effectuation when engaged in new venture formation process (Alsos, Clausen, Hytti, \& Solvoll, 2016). In addition, the level of shared intense positive feelings for a collective and central team identity can also affect new ventures' team and individual member outcomes (Cardon, Post, \& Forster, 2017). Thus, from a multi-level perspective, this collective team identity can in turn affect entrepreneurial decision making in the pursuit of opportunities (Shepherd, 2011)

From a leadership perspective, leaders' identity work can facilitate identity formation in the process of organizational change, such as mergers and acquisitions (Xing \& Liu, 2016). Organizational change also offers the contextual setting to investigate how organization identity (including team identity) can be constructed and transformed (Gioia, Patvardhan, Hamilton, \& Corley, 2013). For instance, a transitional identity can facilitate the organizational identity change during a merger (Clark, Gioia, Ketchen, \& Thomas, 2010). Paradoxical leadership can enable strategic agility by managing different tensions (Lewis, Andriopoulos, \& Smith, 2014). Tensions can be adding new members or from the departure of existing members which can bring dynamics and changes to the team (Forbes et al., 2006). In addition, members of entrepreneurial team may possess diverging psychological needs due to psychological deficit in feelings of belongingness, trust and distinctiveness (Shepherd \& Haynie, 2009). Hence, from an HR perspective in particular, the potential conflicts necessitate effective identity management in entrepreneurial teams. This can also put additional challenges on leadership unity in balancing efficiency and flexibility in agile environments over time (Eisenhardt, Furr, \& Bingham, 2010).

Hence, we posit the following: 
Proposition 3. Entrepreneurial team identity is positively correlated with leadership unity, whereas the more inclusive the team identity is, the more cohesive leadership unity is.

The role of 'speed' as a moderating construct affecting entrepreneurial team agility

'Speed' is considered as a prerequisite for effective agile performance affecting the organizational ability to think and act in a rapid and fast manner. Strategic agility depends on the alertness and commensurate ability of individuals and teams to proactively adapt and manage strategy shifts rapidly in changing environments (Doz \& Kosonen, 2008). Importantly, there are various sub-elements of strategic decision-making which need to be in place for speedy actions or reactions to ensue. Khoshnood and Nematizadeh (2017), for instance, indicate significant positive relations between clarity of vision, core capabilities, selecting strategic targets, shared accountability, team cohesion and taking actions as key elements enabling the organization's ability to modify, improve or develop its capabilities in order to coordinate existing and emerging opportunities. In so doing, they also assert that, speed in execution is critical in order to demonstrate rapid reaction to changing market demands. Taking quick action acknowledges the degree to which an organization accepts how random actions reveal themselves as emerging opportunities make them visible or the organization's speed in having an effective reaction.

There are multiple micro-processes in team dynamics that influence the 'speed' of strategic thought and actions. For instance, research on behavioural integration (BI) in teams (Hambrick, 1994; Li \& Hambrick, 2005; Lubatkin et al., 2006) argue that human interactions within entrepreneurial teams that can be viewed as 'micro-foundations' of team processes that influence speed (Argote \& Ingram, 2000; Felin, Foss, Heimeriks, \& Madsen, 2012; Felin, Foss, \& Ployhart, 2015; Friedman et al., 2016). Specifically, we emphasize BI as comprised of micro- 
behavioural sources which in turn are 'interactions of individuals, processes, and structures that contribute to the aggregation and emergence of the collective constructs' (Felin et al., 2012, p. 3) and is manifested as a strategic capability that affects speed. This is vital for helping us understand how agile entrepreneurial teams are created and sustained, and function with speed as we seek to delineate the HR managerial mechanisms and practices that can foster the strategic agility of such teams.

Moreover, if we want entrepreneurial teams to be quick, then, what does 'being fast' means in different entrepreneurial contexts? Such teams can be fast by flipping a coin, but this clearly sacrifices quality. They might limit the data considered, slash the number of alternatives, and reduce analysis. They might restrict discussion, squash conflict, and centralize the decision. But these too will sacrifice quality, and frustrate management. In a series of analyses, Eisenhardt and her colleagues emphasise on the need to develop an understanding of what more (and less) effective entrepreneurial teams do (in their respective contexts), particularly, where speed is of the essence (Brown \& Eisenhardt, 1997; Eisenhardt, 1990; Eisenhardt \& Bourgeois III, 1988). Specifically, there is a need to understand the kinds of interactions, exchanges and mechanisms that characterise 'speed' within agile entrepreneurial team compositions. A team's speed to process strategic decisions, the traits of its leaders or decision-makers, and the alignment of the its members' psyche, skills and talents, and their ability to resolve conflicts quickly and move on can all shape the performance of agile entrepreneurial teams. This, in turn, make effective team-level HR practices as key drivers enabling agile performance (Dyer \& Shafer, 1998; (Maloney et al., 2016).

Furthermore, speed is seemingly easy in entrepreneurial teams where members that have substantial prior experience of working with each other (Denning, 2017). They seem to have advantages in already having met some of the challenges of working together in innovating or resolving crises and having enough experience together to know how they can be effective as 
a team. Specifically, larger teams, teams with more diversity in age and experience, and teams with a history of working together are much more likely to launch successful entrepreneurial firms quickly and with significant growth potential (Eisenhardt, 2013; Eisenhardt \& Schoonhoven, 1990). These authors explain that large (i.e., 4-5 members) and diverse teams simply have more people with more unique skills and sense-making capabilities to do intense, rigorous and multi-faceted work whilst ensuring the comprehensiveness that may be required in uncertain situations. Teams with experienced members know how to resolve conflicts quickly, hasten team readiness to act, and move forward faster with confidence, and ensure that there are no structural hindrances to execute strategic decisions quickly. These observations help us posit that:

Proposition 4: The speed of strategic decision-making within entrepreneurial teams moderates their strategic agility.

\section{Implications for theoretical development and HRM practices}

The ability to cope effectively in environments characterized by unprecedented, unrelenting, and largely unpredictable change is an ongoing concern. Strategic agility seeks to strive to develop a built-in capacity to shift, flex, and adjust, either alone or with stakeholders, as circumstances change, and to do so with the needed immediacy. The aim is to keep the internal environment of the organization (and within teams) at a level of fluidity and flexibility that matches the degree of turbulence it is facing in the external environment. Increasingly, there is a need for HR strategies, practices and processes to be ready and aligned to foster such agility, but how this is achieved remains an elusive question (Ananthram \& Nankervis, 2013; Shafer et al., 2001). Our review and theoretical model attempts to make some important contributions in this direction. In so doing, we aim to elucidate how HRM concepts and theoretical underpinnings in the context of entrepreneurial team can advance the research on agility. 
Firstly, we decompose the notion of entrepreneurial team and how it manages its speed of decision-making into three key dimensions of entrepreneurial team (cognition, composition, and identity). In so doing, we advance the entrepreneurial team research by building upon the micro-foundation movement (Felin et al., 2015). Furthermore, our study also adds to the recent scholarly conversation on contextualizing teams research by highlighting the significance of entrepreneurial context (Maloney et al., 2016). These authors call for deeper attention to contextual factors and their implications in enabling agile teams (Welter, 2011; Zahra, 2007). Secondly, by linking with the notion of strategic agility, our study utilized entrepreneurial team lens to argue the need to explore the role of speed within strategic agility in differing contexts. Because strategic agility is originally developed in the context of large and established organizations, the distinctive characteristics of SMEs differ largely from MNEs (Stokes et al., 2016) offer novel context to investigate strategic agility. In so doing, we develop propositions linking entrepreneurial team with strategic agility along distinctive conceptual components of agility. Our main contribution lies in articulating the role of speed and how it affects the relationship between entrepreneurial team and its agility in differing entrepreneurial contexts. Our propositions suggest the nuanced and complex relationships that may exist between entrepreneurial team dynamics and its strategic agility in pursuing innovation and entrepreneurial opportunities (Klein, Mahoney, McGahan, \& Pitelis, 2013).

Our study also can contribute to the thought and development of HRM practices that focus on how agile organisations go about defining, developing and refining team level competencies to stay agile, which is a critical issue for sustainable competitive advantage. This extends the original arguments of resource-based theorists (e.g. Barney 1997) who argue that core competencies which are valuable, rare, and inimitable provide at best only a temporary source of competitive advantage. For a sustainable competitive advantage, it is necessary to build capabilities of developing, exploiting, flexing and continuously renewing these competencies, 
and of doing so better, faster, and cheaper than competitors. So what forms of HR activities and practices can foster such agile attributes at individual and team levels remain an important question for sustained competitive advantage. Rather than focusing on broad level HR approaches of enhancing agility, our emphasis suggests determining HR activities and mechanisms to enhance micro team-level agile attributes within individual and teams in respective entrepreneurial contexts.

The focus should be on the complementarities between the focal HR activities and microprocesses that enable speed within agile teams. Eisenhardt and colleagues studies indicate that the 'winning trifecta' of speed, conflict, and getting along within entrepreneurial teams are key to enable effective and fast decisions (Eisenhardt \& Bingham, 2017; Eisenhardt \& Schoonhoven, 1990), the HR related mechanisms and practices involved around simply helping the team to 'get along' fast are not known. We argue that it is important to help HR managers understand the importance of and difficulties involved in developing cohesive, effective and agile entrepreneurial teams (Ananthram \& Nankervis, 2013). The challenge in doing this results from the substantial uncertainties inherent in making these strategic decisions as well as from psychological and organizational biases (Mitroff, 1983) that affect the attention, assessments, and actions of team members in ways that imping on their ability to recognise problems, behave constructively and act in a timely fashion or may cause dissonance leading to erratic, unpredictable and unacceptable behaviour which is in complete contrast with the rational, professional and acceptable team behaviour . Being careful and rational is important but not sufficient if HR managers are to recognize when resource commitments should be halted or reversed and act quickly within entrepreneurial teams. We argue that decision-makers in entrepreneurial teams may become unconsciously trapped in a vicious cycle of insensitivity, self-serving interpretation, and inaction if they fail to develop team cohesion and strong ties that underpin their agility (Carnes, Chirico, Hitt, Huh, \& Pisano, 2017). We emphasise that HR 
managers and their practices should focus on the micro behavioural mechanisms at play within agile entrepreneurial teams that feed and encourage such biases. They should be consistently proactive to overcome such biases quickly in order to avoid team rigidity.

Closely related to the above, researchers have also indicated that collaborative and open teamwork are crucial to coping with complex and ill-structured decisions (Kerr \& Tindale, 2004). Effective and fast strategic decision-making tend to use more information, emphasize continuous interactions with other team members, encourage collaboration over competitiveness, and generally rely on more substantial information and intelligence (Bingham \& Eisenhardt, 2011). Friedman et al (2016), as such, illustrate that high behavioural integration within teams (manifested in increased collaboration and information-sharing among top management team members) is likely to encourage the search and exploration of alternative solutions as well as increased openness to the views and perspectives of other team members so that joint decision-making processes, team collaboration and information-sharing are facilitated and reinforced. This may lead to a process that is more comprehensive and conducive to the sharing of opinions, the exploration of alternative responses to strategic situations, and the utilization of cooperative decision-making procedures to better react to the dynamic competitive environment faced by the organization. In such contexts, Eisenhardt and Schoonhoven (1990) argue that, although, at macro levels, the main effects of top management teams and markets are significant, the underlying interaction effects are even more significantly strong and need to be fostered for agility to pervade and develop. In this respect, it is important to understand how entrepreneurial teams learn, behave, interact and communicate as they engage in essential, repeated decision making processes that underpin their agility such as developing new products, making acquisitions, and entering new countries (Bingham, 2009; Brannen \& Doz, 2012). Thus, there is a need to understand the relevance of learning and team heuristics and behaviours and their effects on strategy and agile team performance. Relatedly, 
HR implications are significant in this respect in understanding the kinds of language, heuristics, behaviour and learning involved in agile entrepreneurial teams and their likely impact on the success or failure of their overall performance.

We argue there that sound HR practices are central to how this process unfolds in agile settings. Our framework suggests that strategic agility is enhanced to the extent that fluid assignments are supported by a set of HR activities that forge an agile team with a sense of common purpose, embed core values, develop competencies, and provide commensurate returns to employees in recognizing their ability to stay agile. At team level, for instance, HR managers needs to consider cognition and identity when recruit new team members. New talent may carry strong imprint to the focal team and affect their ability to act fast. Although talent management tends to be flexible and influx in the context of entrepreneurial team, training and team building activities may strengthen team identity and ties. This in turn can affect the team effectiveness in identifying, evaluating and responding to opportunities in a timely fashion. However, it also needs the collective team cognition in place to shape opportunity discovery and creation process (Sarasvathy, 2001). Further, growth and productivity are priorities for any entrepreneurial teams (Acs \& Mueller, 2008), yet uncertainty exists regarding when and how these teams can best accomplish their goals. One way HR managers can facilitate growth and productivity is through resource investments in HR practices designed to influence employee acquisition, retention, and motivation within entrepreneurial teams (Gardner, Wright, \& Moynihan, 2011). The deployment of such practices represents the strategic layout of a venture's resources toward goal achievement via human capital recruitment, retention, and activation in considerations of the make-up of entrepreneurial teams and what would enhance their agility and effectiveness (Lepak \& Snell, 1998). Identifying factors that determine when and how these investments are successful remains a key goal of research on strategic HR management (HRM) and entrepreneurship (Jackson, Schuler, \& Jiang, 2014; Nyberg \& 
Wright, 2015). Further, this research also contributes to HRM theory by investigating the micro-level factors affecting of speed on entrepreneurial team decision-making, in thinking particularly about human resource fluidity and flexibility dimensions of role modifiability and ability to affect strong ties the working relationship.

Overall, the reasoning here is that strategic agility in entrepreneurial teams is enhanced by paying attention to micro-level agile attributes that affect how quickly thoughts, decisions and actions occur. To a larger extent, organizations should focus in investing in complementary HR activities that increase employees' and their teams' sense of common purpose with the organization, internalization of selected core values within teams, match eagerness and ability to develop both technical and personal competencies affecting agility, and sense of receiving intangible and tangible returns commensurate with their inputs and contributions. Although the analysis in the present study is only suggestive, our framework does provide a baseline from which to dig more deeply, at micro level, into the alignment of HR activities in agile settings.

\section{Future research agenda}

Several future research directions await further scholarly investigation in the direction set out by this paper. Firstly, there is the need to examine additional micro-foundations for strategic agility. The behavioural integration perspective enables us to identify speed and associated micro-level processes as important micro-foundation for entrepreneurial teams to pursue and sustain agility. Furthermore, our analysis on cognition and identity can serve as departure point to further explore the human side factors to facilitate strategic agility, such as emotion or resilience (Cooper et al., 2014). Secondly, future research can take into account the development stage of ventures by examining nascent entrepreneurial ventures vs. maturing firms (Liu, 2017). For instance, one study found out that maturing born-global firms tend to internalize HRM practices and foster commitment compared to early stage born-global firms 
(Glaister, Liu, Sahadev, \& Gomes, 2014). Therefore, a life cycle perspective on entrepreneurial teams may reveal other mechanisms that connect with strategic agility. The speed of decisionmaking process may be significantly affected when firms become larger and mature. Thus, the future research can compare the influence of speed and decision making along the different stages of organization development. Thirdly, globalization and entrepreneurial mobility (Wang \& Liu, 2016) may present new challenges and opportunities for entrepreneurial firms to remain agile. International dimension can significantly affect team cognition, composition and identity that in turn can influence the way entrepreneurs pursue opportunities and manage resources (Sarasvathy, Kumar, York, \& Bhagavatula, 2014). Importantly, emerging economies may present rewarding opportunities for entrepreneurial teams while interacting with other important actors, including local government (Xing, Liu, \& Cooper, 2018), universities (Liu \& Huang, 2018), and multinational enterprises (Collinson \& Liu, 2017; Liu, Öberg, Tarba, \& Xing, 2018; Xing, Liu, Tarba, \& Cooper, 2017; Xing, Liu, Tarba, \& Cooper, 2016) to develop and transform the larger institutional environment. Last but not least, we encourage future research to expand our conceptualization by connecting with adjacent concepts, such as ambidexterity (Junni, Sarala, Tarba, Liu, \& Cooper, 2015; Xing, Liu, Tarba, \& Wood, 2016). Future research can also take a liberal approach in defining the HR agility, beyond strategic agility in a much broader sense. So that cross-fertilization with adjacent concepts, such as ambidexterity, may engender revealing insights in the context of entrepreneurial team and its agility.

\section{References}

Acs, Z. J., \& Mueller, P. 2008. Employment effects of business dynamics: Mice, gazelles and elephants. Small Business Economics, 30(1): 85-100.

Alsos, G. A., Clausen, T. H., Hytti, U., \& Solvoll, S. 2016. Entrepreneurs' social identity and the preference of causal and effectual behaviours in start-up processes. Entrepreneurship \& Regional Development, 28(3-4): 234-258. 
Ananthram, S., \& Nankervis, A. 2013. Strategic agility and the role of HR as a strategic business partner: an Indian perspective. Asia Pacific Journal of Human Resources, 51(4): 454-470.

Argote, L., \& Ingram, P. 2000. Knowledge transfer: A basis for competitive advantage in firms. Organizational behavior and human decision processes, 82(1): 150-169.

Beckman, C. M., Burton, M. D., \& O'Reilly, C. 2007. Early teams: The impact of team demography on VC financing and going public. Journal of Business Venturing, 22(2): 147-173.

Bingham, C. B. 2009. Oscillating improvisation: How entrepreneurial firms create success in foreign market entries over time. Strategic Entrepreneurship Journal, 3(4): 321-345.

Bingham, C. B., \& Eisenhardt, K. M. 2011. Rational heuristics: the 'simple rules' that strategists learn from process experience. Strategic Management Journal, 32(13): 1437-1464.

Bingham, C. B., Furr, N. R., \& Eisenhardt, K. M. 2014. The opportunity paradox. MIT Sloan Management Review, 56(1): 29.

Blatt, R. 2009. Tough love: How communal schemas and contracting practices build relational capital in entrepreneurial teams. Academy of Management Review, 34(3): 533-551.

Boojihawon, D. K., Dimitratos, P., \& Young, S. 2007. Characteristics and influences of multinational subsidiary entrepreneurial culture: The case of the advertising sector. International Business Review, 16(5): 549-572.

Bottani, E. 2009. A fuzzy QFD approach to achieve agility. International Journal of Production Economics, 119(2): 380-391.

Brannen, M. Y., \& Doz, Y. L. 2012. Corporate Languages and Strategic Agility. California Management Review, 54(3): 77-97.

Brown, S. L., \& Eisenhardt, K. M. 1997. The art of continuous change: Linking complexity theory and time-paced evolution in relentlessly shifting organizations. Administrative Science Quarterly, 42(1): 1-34.

Bryant, P. T. 2014. Imprinting by design: The microfoundations of entrepreneurial adaptation. Entrepreneurship Theory and Practice, 38(5): 1081-1102.

Bustinza, O. F., Gomes, E., Vendrell - Herrero, F., \& Tarba, S. Y. 2018. An organizational change framework for digital servitization: Evidence from the Veneto region. Strategic Change, 27(2): 111-119.

Cao, Q., Simsek, Z., \& Zhang, H. 2010. Modelling the joint impact of the CEO and the TMT on organizational ambidexterity. Journal of Management Studies, 47(7): 1272-1296.

Cardon, M. S., Post, C., \& Forster, W. R. 2017. Team entrepreneurial passion: Its emergence and influence in new venture teams. Academy of Management Review, 42(2): 283-305.

Carmeli, A., Schaubroeck, J., \& Tishler, A. 2011. How CEO empowering leadership shapes top management team processes: Implications for firm performance. The Leadership Quarterly, 22(2): 399-411.

Carmeli, A., Zivan, I., Gomes, E., \& Markman, G. D. 2017. Underlining micro socio-psychological mechanisms of buyer-supplier relationships: Implications for inter-organizational learning agility. Human Resource Management Review, Available online 3 January 2017.

Carnes, C. M., Chirico, F., Hitt, M. A., Huh, D. W., \& Pisano, V. 2017. Resource orchestration for innovation: Structuring and bundling resources in growth-and maturity-stage firms. Long Range Planning, 50(4): 472-486.

Chandler, G. N., Honig, B., \& Wiklund, J. 2005. Antecedents, moderators, and performance consequences of membership change in new venture teams. Journal of Business Venturing, 20(5): 705-725.

Chowdhury, S. 2005. Demographic diversity for building an effective entrepreneurial team: is it important? Journal of Business Venturing, 20(6): 727-746.

Clark, S. M., Gioia, D. A., Ketchen, D. J., \& Thomas, J. B. 2010. Transitional identity as a facilitator of organizational identity change during a merger. Administrative science quarterly, 55(3): 397-438.

Clarysse, B., \& Moray, N. 2004. A process study of entrepreneurial team formation: the case of a research-based spin-off. Journal of Business Venturing, 19(1): 55-79.

Coff, R., \& Raffiee, J. 2015. Toward a Theory of Perceived Firm-Specific Human Capital. The Academy of Management Perspectives, 29(3): 326-341. 
Collinson, S., \& Liu, Y. 2017. Recombination for Innovation: Performance Outcomes from International Partnerships in China. R\&D Management, Forthcoming.

Cooper, C. L., Liu, Y., \& Tarba, S. Y. 2014. Resilience, HRM practices and impact on organizational performance and employee well-being: International Journal of Human Resource Management 2015 Special Issue. The International Journal of Human Resource Management, 25(17): 2466-2471.

Cyert, R. M., \& March, J. G. 1963. A behavioral theory of the firm. Englewood Cliffs, NJ: PrenticeHall.

Denning, S. 2017. The age of Agile. Strategy \& Leadership, 45(1): 3-10.

Doz, Y. L., \& Kosonen, M. 2008. Fast strategy: How strategic agility will help you stay ahead of the game: Pearson Education.

Doz, Y. L., \& Kosonen, M. 2010. Embedding strategic agility: A leadership agenda for accelerating business model renewal. Long range planning, 43(2): 370-382.

Dufays, F., \& Huybrechts, B. 2016. Where do hybrids come from? Entrepreneurial team heterogeneity as an avenue for the emergence of hybrid organizations. International Small Business Journal, 34(6): 777-796.

Eisenhardt, K. M. 1990. Speed and strategic choice: How managers accelerate decision making. California Management Review, 32(3): 39-54.

Eisenhardt, K. M. 2013. Top management teams and the performance of entrepreneurial firms. Small Business Economics, 40(4): 805-816.

Eisenhardt, K. M., \& Bingham, C. B. 2017. Superior Strategy in Entrepreneurial Settings: Thinking, Doing, and the Logic of Opportunity. Strategy Science, 2(4): 246-257.

Eisenhardt, K. M., \& Bourgeois III, L. J. 1988. Politics of strategic decision making in high-velocity environments: Toward a midrange theory. Academy of Management Journal, 31(4): 737770 .

Eisenhardt, K. M., Furr, N. R., \& Bingham, C. B. 2010. CROSSROADS-Microfoundations of performance: Balancing efficiency and flexibility in dynamic environments. Organization Science, 21(6): 1263-1273.

Eisenhardt, K. M., \& Schoonhoven, C. B. 1990. Organizational growth: Linking founding team, strategy, environment, and growth among US semiconductor ventures, 1978-1988. Administrative Science Quarterly, 35(3): 504-529.

Eisenhardt, K. M., \& Zbaracki, M. J. 1992. Strategic decision making. Strategic management journal, 13(S2): 17-37.

Ensley, M. D., \& Pearce, C. L. 2001. Shared cognition in top management teams: Implications for new venture performance. Journal of Organizational Behavior, 22(2): 145-160.

Ensley, M. D., Pearson, A., \& Pearce, C. L. 2003. Top management team process, shared leadership, and new venture performance: A theoretical model and research agenda. Human Resource Management Review, 13(2): 329-346.

Ensley, M. D., Pearson, A. W., \& Amason, A. C. 2002. Understanding the dynamics of new venture top management teams: cohesion, conflict, and new venture performance. Journal of business venturing, 17(4): 365-386.

Fauchart, E., \& Gruber, M. 2011. Darwinians, communitarians, and missionaries: The role of founder identity in entrepreneurship. Academy of management journal, 54(5): 935-957.

Felin, T., Foss, N. J., Heimeriks, K. H., \& Madsen, T. L. 2012. Microfoundations of routines and capabilities: Individuals, processes, and structure. Journal of Management Studies, 49(8): 1351-1374.

Felin, T., Foss, N. J., \& Ployhart, R. E. 2015. The microfoundations movement in strategy and organization theory. The Academy of Management Annals, 9(1): 575-632.

Forbes, D. P., Borchert, P. S., Zellmer - Bruhn, M. E., \& Sapienza, H. J. 2006. Entrepreneurial team formation: An exploration of new member addition. Entrepreneurship Theory and Practice, 30(2): 225-248.

Friedman, Y., Carmeli, A., \& Tishler, A. 2016. How CEOs and TMTs build adaptive capacity in small entrepreneurial firms. Journal of Management Studies, 53(6): 996-1018.

Ganguly, A., Nilchiani, R., \& Farr, J. V. 2009. Evaluating agility in corporate enterprises. International Journal of Production Economics, 118(2): 410-423. 
Gardner, T. M., Wright, P. M., \& Moynihan, L. M. 2011. The impact of motivation, empowerment, and skill - enhancing practices on aggregate voluntary turnover: The mediating effect of collective affective commitment. Personnel psychology, 64(2): 315-350.

Gavetti, G., Greve, H. R., Levinthal, D. A., \& Ocasio, W. 2012. The behavioral theory of the firm: Assessment and prospects. Academy of Management Annals, 6(1): 1-40.

Gedajlovic, E., Honig, B., Moore, C. B., Payne, G. T., \& Wright, M. 2013. Social capital and entrepreneurship: A schema and research agenda. Entrepreneurship Theory and Practice, 37(3): 455-478.

Gioia, D. A., Patvardhan, S. D., Hamilton, A. L., \& Corley, K. G. 2013. Organizational identity formation and change. The Academy of Management Annals, 7(1): 123-193.

Glaister, A. J., Liu, Y., Sahadev, S., \& Gomes, E. 2014. Externalizing, internalizing and fostering commitment: The case of born-global firms in emerging economies. Management international review, 54(4): 473-496.

Glassman, A. M., Zell, D., \& Duron, S. 2014. Thinking Strategically in Turbulent Times: An Inside View of Strategy Making: An Inside View of Strategy Making. New York: Routledge.

Gruber, M., \& MacMillan, I. C. 2017. Entrepreneurial behavior: A reconceptualization and extension based on identity theory. Strategic Entrepreneurship Journal, 11(3): 271-286.

Hambrick, D. C. 1994. Top management groups: A conceptual integration and reconsideration of the "team" label. In B. M. Staw, \& L. L. Cummings (Eds.), Research in organizational behaviour, Vol. 16: 171-213. Greenwich, CT: JAI Press.

Hambrick, D. C. 2007. Upper echelons theory: An update. Academy of Management Review, 32(2): 334-343.

Hayton, J. C. 2005. Promoting corporate entrepreneurship through human resource management practices: A review of empirical research. Human Resource Management Review, 15(1): 2141.

Hmieleski, K. M., \& Ensley, M. D. 2007. A contextual examination of new venture performance: entrepreneur leadership behavior, top management team heterogeneity, and environmental dynamism. Journal of Organizational Behavior, 28(7): 865-889.

Hsu, D. H. 2007. Experienced entrepreneurial founders, organizational capital, and venture capital funding. Research Policy, 36(5): 722-741.

Jackson, S. E., Schuler, R. S., \& Jiang, K. 2014. An aspirational framework for strategic human resource management. The Academy of Management Annals, 8(1): 1-56.

Jennings, P., \& Beaver, G. 1997. The performance and competitive advantage of small firms: a management perspective. International Small Business Journal, 15(2): 63-75.

Junni, P., Sarala, R. M., Tarba, S. Y., Liu, Y., \& Cooper, C. L. 2015. Guest Editors' Introduction: The Role of Human Resources and Organizational Factors in Ambidexterity. Human Resource Management, 54(S1): s1-s28.

Junni, P., Sarala, R. M., Tarba, S. Y., \& Weber, Y. 2015. The Role of Strategic Agility in Acquisitions. British Journal of Management, Article first published online: 19 MAY 2015.

Kerr, N. L., \& Tindale, R. S. 2004. Group performance and decision making. Annual Review of Psychology, 55: 623-655.

Khoshnood, N. T., \& Nematizadeh, S. 2017. Strategic Agility and Its Impact on the Competitive Capabilities in Iranian Private Banks. International Journal of Business and Management, 12(2): 220-229.

Klein, P. G., Mahoney, J. T., McGahan, A. M., \& Pitelis, C. N. 2013. Capabilities and strategic entrepreneurship in public organizations. Strategic Entrepreneurship Journal, 7(1): 70-91.

Klotz, A. C., Hmieleski, K. M., Bradley, B. H., \& Busenitz, L. W. 2014. New venture teams a review of the literature and roadmap for future research. Journal of Management, 40(1): 226-255.

Knockaert, M., Bjornali, E. S., \& Erikson, T. 2015. Joining forces: Top management team and board chair characteristics as antecedents of board service involvement. Journal of Business Venturing, 30(3): 420-435.

Knockaert, M., Ucbasaran, D., Wright, M., \& Clarysse, B. 2011. The relationship between knowledge transfer, top management team composition, and performance: the case of science - based entrepreneurial firms. Entrepreneurship Theory and Practice, 35(4): 777-803. 
Kroll, M., Walters, B. A., \& Le, S. A. 2007. The impact of board composition and top management team ownership structure on post-IPO performance in young entrepreneurial firms. Academy of Management Journal, 50(5): 1198-1216.

Kunc, M. H., \& Morecroft, J. D. 2010. Managerial decision making and firm performance under a resource - based paradigm. Strategic Management Journal, 31(11): 1164-1182.

Leitch, C. M., \& Harrison, R. T. 2016. Identity, identity formation and identity work in entrepreneurship: conceptual developments and empirical applications. Entrepreneurship \& Regional Development, 28(3-4): 177-190.

Lepak, D. P., \& Snell, S. A. 1998. Virtual HR: Strategic human resource management in the 21st century. Human Resource Management Review, 8(3): 215-234.

Lewis, M. W., Andriopoulos, C., \& Smith, W. K. 2014. Paradoxical leadership to enable strategic agility. California Management Review, 56(3).

Li, J., \& Hambrick, D. C. 2005. Factional groups: A new vantage on demographic faultlines, conflict, and disintegration in work teams. Academy of Management Journal, 48(5): 794-813.

Liu, M.-L., Liu, N.-T., Ding, C. G., \& Lin, C.-P. 2015. Exploring team performance in high-tech industries: Future trends of building up teamwork. Technological Forecasting and Social Change, 91: 295-310.

Liu, Y. 2017. Born global firms' growth and collaborative entry mode: the role of transnational entrepreneurs. International Marketing Review, 34(1): 46-67.

Liu, Y. 2018. Contextualizing risk and building resilience: returnees versus local entrepreneurs in China. Applied Psychology: An International Review, Forthcoming.

Liu, Y., \& Almor, T. 2016. How culture influences the way entrepreneurs deal with uncertainty in inter-organizational relationships: The case of returnee versus local entrepreneurs in China. International Business Review, 25(1): 4-14.

Liu, Y., \& Huang, Q. 2018. University capability as a micro-foundation for the Triple Helix model: The case of China. Technovation, Available online 14 March 2018.

Liu, Y., \& Isaak, A. 2016. Effectuation spectra in chinese high-tech entrepreneurship: Domainspecific logic orientations and cross-border M\&A. In S. Y. Tarba, \& Y. Weber (Eds.), Mergers and Acquisitions, Entrepreneurship and Innovation: 111-148: Emerald Group Publishing Limited.

Liu, Y., Öberg, C., Tarba, S. Y., \& Xing, Y. 2018. Brand management in Mergers and Acquisitions: Emerging market multinationals venturing into advanced economies. International Marketing Review, 35(5): Forthcoming.

Lubatkin, M. H., Simsek, Z., Ling, Y., \& Veiga, J. F. 2006. Ambidexterity and performance in smallto medium-sized firms: The pivotal role of top management team behavioral integration. Journal of management, 32(5): 646-672.

Maloney, M. M., Bresman, H., Zellmer-Bruhn, M. E., \& Beaver, G. R. 2016. Contextualization and Context Theorizing in Teams Research: A Look Back and a Path Forward. The Academy of Management Annals: 1-52.

Mathias, B. D., \& Williams, D. W. 2014. The Impact of Role Identities on Entrepreneurs' Evaluation and Selection of Opportunities. Journal of Management: 0149206314544747.

Miller, C. C., \& Ireland, R. D. 2005. Intuition in strategic decision making: friend or foe in the fastpaced 21st century? The Academy of Management Executive, 19(1): 19-30.

Mitroff, I. I. 1983. Archetypal social systems analysis: On the deeper structure of human systems. Academy of Management Review, 8(3): 387-397.

Mohrman, S. A., \& Worley, C. G. 2009. Dealing with rough times: A capabilities development approach to surviving and thriving. Human Resource Management, 48(3): 433-445.

Mol, E., Khapova, S. N., \& Elfring, T. 2015. Entrepreneurial team cognition: A review. International Journal of Management Reviews, 17(2): 232-255.

Mosey, S., \& Wright, M. 2007. From human capital to social capital: A longitudinal study of technology - based academic entrepreneurs. Entrepreneurship theory and practice, 31(6): 909-935. 
Nadkarni, S., \& Herrmann, P. 2010. CEO personality, strategic flexibility, and firm performance: The case of the Indian business process outsourcing industry. Academy of Management Journal, 53(5): 1050-1073.

Nason, R. S., \& Wiklund, J. 2015. An assessment of resource-based theorizing on firm growth and suggestions for the future. Journal of Management: published on October 27, 2015.

Navis, C., \& Glynn, M. A. 2010. How new market categories emerge: Temporal dynamics of legitimacy, identity, and entrepreneurship in satellite radio, 1990-2005. Administrative Science Quarterly, 55(3): 439-471.

Navis, C., \& Glynn, M. A. 2011. Legitimate distinctiveness and the entrepreneurial identity: Influence on investor judgments of new venture plausibility. Academy of Management Review, 36(3): 479-499.

Nijssen, M., \& Paauwe, J. 2012. HRM in turbulent times: how to achieve organizational agility? The International Journal of Human Resource Management, 23(16): 3315-3335.

Nyberg, A. J., \& Wright, P. M. 2015. 50 years of human capital research: assessing what we know, exploring where we go. The Academy of Management Perspectives, 29(3): 287-295.

Okhuysen, G. A., \& Eisenhardt, K. M. 2002. Integrating knowledge in groups: How formal interventions enable flexibility. Organization Science, 13(4): 370-386.

Ott, T. E., Eisenhardt, K. M., \& Bingham, C. B. 2017. Strategy formation in entrepreneurial settings: Past insights and future directions. Strategic Entrepreneurship Journal.

Packalen, K. A. 2007. Complementing capital: The role of status, demographic features, and social capital in founding teams' abilities to obtain resources. Entrepreneurship Theory and Practice, 31(6): 873-891.

Ployhart, R. E., \& Moliterno, T. P. 2011. Emergence of the human capital resource: A multilevel model. Academy of Management Review, 36(1): 127-150.

Powell, E. E., \& Baker, T. 2014. It's what you make of it: founder identity and enacting strategic responses to adversity. Academy of Management Journal, 57(5): 1406-1433.

Sarasvathy, S., Kumar, K., York, J. G., \& Bhagavatula, S. 2014. An effectual approach to international entrepreneurship: Overlaps, challenges, and provocative possibilities. Entrepreneurship Theory and Practice, 38(1): 71-93.

Sarasvathy, S. D. 2001. Causation and effectuation: Toward a theoretical shift from economic inevitability to entrepreneurial contingency. Academy of Management Review, 26(2): 243263.

Shafer, R. A., Dyer, L., Kilty, J., Amos, J., \& Ericksen, J. 2001. Crafting a human resource strategy to foster organizational agility: A case study. Human Resource Management, 40(3): 197-211.

Shepherd, D., \& Haynie, J. M. 2009. Birds of a feather don't always flock together: Identity management in entrepreneurship. Journal of Business Venturing, 24(4): 316-337.

Shepherd, D. A. 2011. Multilevel entrepreneurship research: Opportunities for studying entrepreneurial decision making. Journal of Management, 37(2): 412-420.

Shepherd, D. A., \& Krueger, N. F. 2002. An intentions - based model of entrepreneurial teams' social cognition. Entrepreneurship Theory and Practice, 27(2): 167-185.

Snell, S. A., Snow, C. C., Davison, S. C., \& Hambrick, D. C. 1998. Designing and supporting transnational teams: The human resource agenda. Human Resource Management, 37(2): 147-158.

Stokes, P., Liu, Y., Smith, S., Leidner, S., Moore, N., \& Rowland, C. 2016. Managing talent across advanced and emerging economies: HR issues and challenges in a Sino-German strategic collaboration. The International Journal of Human Resource Management, 27(20): 23102338.

Teece, D., Peteraf, M., \& Leih, S. 2016. Dynamic capabilities and organizational agility: Risk, uncertainty, and strategy in the innovation economy. California Management Review, 58(4): 13-35.

Ucbasaran, D., Lockett, A., Wright, M., \& Westhead, P. 2003. Entrepreneurial founder teams: Factors associated with member entry and exit. Entrepreneurship Theory and Practice, 28(2): 107128.

Ucbasaran, D., Westhead, P., \& Wright, M. 2008. Opportunity identification and pursuit: does an entrepreneur's human capital matter? Small Business Economics, 30(2): 153-173. 
Unger, J. M., Rauch, A., Frese, M., \& Rosenbusch, N. 2011. Human capital and entrepreneurial success: A meta-analytical review. Journal of Business Venturing, 26(3): 341-358.

van Werven, R., Bouwmeester, O., \& Cornelissen, J. P. 2015. The power of arguments: How entrepreneurs convince stakeholders of the legitimate distinctiveness of their ventures. Journal of Business Venturing, 30(4): 616-631.

Vissa, B., \& Chacar, A. S. 2009. Leveraging ties: the contingent value of entrepreneurial teams' external advice networks on Indian software venture performance. Strategic Management Journal, 30(11): 1179-1191.

Wang, H., \& Liu, Y. 2016. Entrepreneurship and Talent Management from a Global Perspective: Global Returnees. Cheltenham: Edward Elgar.

Weber, Y., \& Tarba, S. Y. 2014. Strategic agility: A state of the art. California management review, 56(3): 5-12.

Welter, F. 2011. Contextualizing entrepreneurship - conceptual challenges and ways forward. Entrepreneurship Theory and Practice, 35(1): 165-184.

West, G. P. 2007. Collective cognition: When entrepreneurial teams, not individuals, make decisions. Entrepreneurship Theory and Practice, 31(1): 77-102.

Wright, M., Hmieleski, K. M., Siegel, D. S., \& Ensley, M. D. 2007. The role of human capital in technological entrepreneurship. Entrepreneurship Theory and Practice, 31(6): 791-806.

Wright, M., \& Vanaelst, I. 2009. Entrepreneurial teams and new business creation: Edward Elgar.

Wry, T., Lounsbury, M., \& Jennings, P. D. 2014. Hybrid Vigor: Securing Venture Capital by Spanning Categories in Nanotechnology. Academy of Management Journal, 57(5): 13091333.

Xing, Y. 2016. A Daoist Reflection on Sea-Like Leadership and Enlightened Thinking. Management and Organization Review, 12(4): 807-810.

Xing, Y., \& Liu, Y. 2015. Poetry and Leadership in Light of Ambiguity and Logic of Appropriateness. Management and Organization Review, 11(4): 763-793.

Xing, Y., \& Liu, Y. 2016. Linking leaders' identity work and human resource management involvement: the case of sociocultural integration in Chinese mergers and acquisitions. The International Journal of Human Resource Management, 27(20): 2550-2577.

Xing, Y., Liu, Y., \& Cooper, C. L. 2018. Local Government as Institutional Entrepreneur: Collaborative Partnerships in Fostering Regional Entrepreneurship. British Journal of Management, First published: 27 February 2018.

Xing, Y., Liu, Y., Tarba, S., \& Cooper, C. L. 2017. Servitization in Mergers and Acquisitions: Manufacturing Firms Venturing from Emerging Markets into Advanced Economies. International Journal of Production Economics, 192(October): 9-18.

Xing, Y., Liu, Y., Tarba, S., \& Wood, G. 2016. A cultural inquiry into ambidexterity in supervisorsubordinate relationship. The International Journal of Human Resource Management: 129.

Xing, Y., Liu, Y., Tarba, S. Y., \& Cooper, C. L. 2016. Intercultural influences on managing African employees of Chinese firms in Africa: Chinese managers' HRM practices. International Business Review, 25(1): 28-41.

Zahra, S. A. 2007. Contextualizing theory building in entrepreneurship research. Journal of Business venturing, 22(3): 443-452.

Zimmerman, M. A. 2008. The influence of top management team heterogeneity on the capital raised through an initial public offering. Entrepreneurship Theory and Practice, 32(3): 391-414. 
Figure 1. A conceptual framework on entrepreneurial team and strategic agility

\section{Entrepreneurial team}

Strategic agility
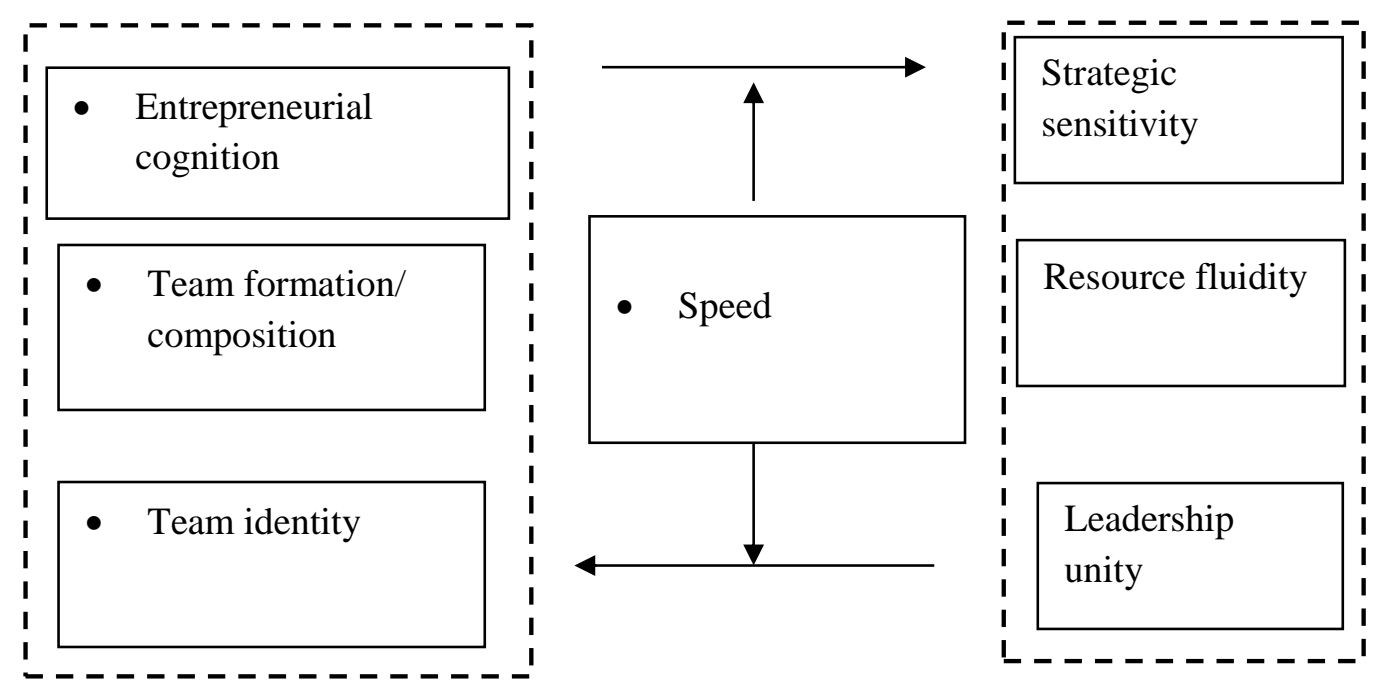